\title{
Methodology for classification of land use and vegetation cover using MODIS-EVI data
}

\author{
Vagner P. Mengue ${ }^{1}$, Denise C. Fontana ${ }^{2}$, Tatiana S. da Silva ${ }^{3}$, Daniel Zanotta ${ }^{4} \&$ Fernando C. Scottá $^{5}$
}

\begin{abstract}
${ }^{1}$ Universidade Federal do Rio Grande do Sul/Centro Estadual de Pesquisas em Sensoriamento Remoto e Meteorologia. Porto Alegre, RS, Brasil. E-mail: vagnergeo@yahoo.com.br (Corresponding author) - ORCID: 0000-0002-2955-1039

${ }^{2}$ Universidade Federal do Rio Grande do Sul/Departamento de Plantas Forrageiras e Agrometeorologia. Porto Alegre, RS, Brasil. E-mail: dfontana@ufrgs.br ORCID: 0000-0002-2635-6086

${ }^{3}$ Universidade Federal do Rio Grande do Sul/Departamento de Geodésia/Instituto de Geociências. Porto Alegre, RS, Brasil. E-mail: tatiana.silva@ufrgs.br ORCID: 0000-0002-7234-0042

${ }^{4}$ Instituto Federal de Educação, Ciência e Tecnologia do Rio Grande do Sul/Curso de Geoprocessamento/Laboratório de Geotecnologias na Gestão Municipal. Rio Grande, RS, Brasil. E-mail: daniel.zanotta@riogrande.ifrs.edu.br - ORCID: 0000-0003-2959-6525

${ }^{5}$ Universidade Federal do Rio Grande do Sul/Programa de Pós-Graduação em Geociências. Porto Alegre, RS, Brasil. E-mail: fcscotta@gmail.com - ORCID: 0000-0003-3997-8420
\end{abstract}

\begin{abstract}
This study aimed to verify the applicability of using MODIS-EVI sensor time series for land use and vegetation cover mapping in the Pampa biome, Rio Grande do Sul state, Brazil. The study period comprised the months from June 2013 to June 2014. The procedures included the use of MODIS Sensor images, altimetric data and nighttime images, associated with a hierarchical decision tree classifier, constructed using the C4.5 algorithm. The proposed approach stems from the consideration that the study area has varying characteristics and, therefore, should be treated simultaneously by different and intuitive classifiers, which justifies the choice of decision tree. To evaluate the results, reference data acquired from Landsat 8-OLI satellite images and IBGE data were used. The classification using the MODIS time series showed a global accuracy of $90.09 \%$ and Kappa index of 0.8885 . When compared to the IBGE reference data, the Soybean class obtained a correlation coefficient of 0.94 , the rice class obtained 0.97 and the silviculture class obtained the lowest value, 0.78 . The highest spectral similarities were found in the vegetation cover classes, such as grassland, forest and silviculture. Therefore, with the use of multitemporal data from the MODIS sensor, combined with the use of altimetric data and nighttime images, it is possible to generate a land use and vegetation cover map for the Pampa biome with an acceptable accuracy, considering the MODIS sensor resolution limitations.
\end{abstract}

Key words: decision tree, soybean, multitemporal

\section{Metodologia para classificação de uso do solo e cobertura vegetal utilizando dados MODIS-EVI}

RESUMO: Objetivou-se neste estudo verificar a aplicabilidade do uso de séries temporais do sensor MODISEVI para o mapeamento do uso do solo e cobertura vegetal no Bioma Pampa no Estado do Rio Grande do Sul. O período de estudo compreendeu os meses de junho de 2013 até junho de 2014. Os procedimentos incluíram a utilização de imagens do Sensor MODIS, dados altimétricos e imagens noturnas, associados ao classificador hierárquico por árvore de decisão, construído utilizando o algoritmo C4.5. A abordagem proposta tem origem na consideração de que a área de estudo apresenta características variadas e, por isso, deve ser tratada simultaneamente por classificadores diferentes e intuitivos, o que justifica a escolha da árvore de decisão. Para avaliar os resultados, foram usados dados de referências extraídos de imagens do satélite Landsat 8-OLI e dados do IBGE. Na classificação utilizando a série temporal MODIS, foi encontrada uma exatidão global de 90,09\% e o índice Kappa de 0,8853. Com relação aos dados de referência do IBGE, a classe soja obteve um coeficiente de correlação de 0,94, a classe arroz 0,97 e a classe Silvicultura obteve o menor valor com 0,78 . As maiores similaridades espectrais foram encontradas nas classes com cobertura vegetal, como campo, floresta e silvicultura. Portanto, com o uso de dados multitemporais do sensor MODIS, combinado ao uso de dados altimétricos e imagens noturnas, é possível a geração de um mapa de uso do solo e cobertura vegetal para o bioma Pampa com exatidão aceitável, considerando as limitações da resolução do sensor MODIS.

Palavras-chave: árvore de decisão, soja, multitemporal 


\section{INTRODUCTION}

The Pampa biome, Southern Brazil, has shown land use and vegetation cover changes in the last years, notably due to the conversion of grassland areas to grain farming or silviculture (Maraschin, 2009). There is a great concern in terms of environmental sustainability regarding the Pampa biome, once land use and vegetation cover conversions can cause soil losses by erosion and groundwater contamination by agrochemicals and fertilizers, among other issues. Therefore, there is a need for a continuous monitoring of the land use and vegetation cover transformations in this biome.

Vegetation indices derived from MODIS sensor have been used in a wide variety of applications, with the purpose of mapping and monitoring land use and vegetation cover. A particular example is the study of Liu et al. (2011), who worked with the land use changes between 1982-2009 in Northeast Asia, using normalized difference vegetation index (NDVI) from three different sensors (AVHRR, SPOT and MODIS). In addition, there are some studies based on the spectral-temporal attributes of agricultural crops (Epiphanio et al., 2010; Johann et al., 2012; Brown et al., 2013; Zhou et al., 2013).

Nighttime light data of the DMSP (Defense Meteorological Satellite Program-Operational Linescan System) have been used for several studies, especially for the identification of urban areas (Cao et al., 2009; Lin et al., 2014). Altimetric data of the SRTM (Shuttle Radar Topography Mission) can be used as input data to generate hydrological models, identify areas susceptible to flooding, and it is useful for mapping some land uses, especially agricultural areas, such as irrigated rice. The HAND (Height Above Nearest Drainage) model has been used in the mapping of the stationary hydrological condition of the terrain and also in the mapping of areas susceptible to flooding (Rennó et al., 2008; Nobre et al., 2011).

Studies using decision trees (DT) have shown to be suitable for land use and vegetation cover mapping, since they allow performing classifications and data mining with a large volume of data. In this context, this study aimed to propose a methodology for land use and vegetation cover classification in large areas using MODIS-EVI time series, SRTM elevation model and nighttime images (DMSP-OLS), and employing a hierarchical DT classifier, constructed using the C4.5 algorithm for the entire Pampa biome located in the Rio Grande do Sul state, Southern Brazil.

\section{Material ANd Methods}

The study was conducted in the Pampa Gaúcho biome (IBGE, 2004) within the boundaries of Rio Grande do Sul state, Southern Brazil, between latitudes $28^{\circ} 8^{\prime} \mathrm{S}$ and $33^{\circ} 45^{\prime} \mathrm{S}$ and longitudes $49^{\circ} 80^{\prime} \mathrm{W}$ and $56^{\circ} 20^{\prime} \mathrm{W}$. The study area covers a total of 106 municipalities belonging to the Pampa biome and has a total area of $16,579,332$ ha and a total population of $5,373,216$ inhabitants, which corresponds to $50.24 \%$ of the total population of Rio Grande do Sul state, Brazil (IBGE, 2017).

Regarding the climate, according to the classification of Köppen (1948), Cfa type (rainy subtropical with hot summers) prevails in most of the Pampa biome, and only the region of Serra do Sudeste (Southeastern Mountain Ranges), with higher altitudes ( $\sim 400 \mathrm{~m}$ of altitude), has a Cfb climate (rainy subtropical with mild summers).

This study tested images from TERRA satellite, MODIS sensor, MOD13Q1 product, collection 6, which contains 16 days image compositions in the form of enhanced vegetation index (EVI) vegetation indexes, with a spatial resolution of $250 \mathrm{~m}$. A total of 23 MODIS images, from June 2013 to July 2014, were used to compose the EVI time series.

A total of 23 pixel reliability images were also obtained for the same period and used for filtering in order to reduce noise interference from the presence of clouds, detector failures, geometric distortions, among others, and smooth the spectral-temporal curve. This procedure was performed with the TIMESAT software (Jönsson \& Eklundh, 2004). Data relative to pixel reliability images were categorized and weighted in TIMESAT. The parameters used for filtering the data series, using the Savitzky-Golay filter, were: moving window 4 , adaptation strength 2 , spike method equals to 3 , and number of envelope iterations equals to 2 .

The study used SRTM elevation data (NASA, 2000), with spatial resolution of $30 \mathrm{~m}$, and the DMSP-OLS nighttime light images, with spatial resolution of $550 \mathrm{~m}$. Stable light image option was chosen, which is an annual cloud-free average composite, where ephemeral lights are removed based on their high brightness and short duration, keeping only the sources of permanent light, which are characteristic of urban areas.

Training and validation samples were selected from the Landsat 8/OLI images with spatial resolution of $30 \mathrm{~m}$. In total, 13 scenes with dates between October 2013 and February 2014 were used. Finally, the samples were checked using the Vegetation Temporal Analysis System - SATVeg (SATVEG, 2016), implemented by Embrapa Agricultural Informatics, and a spectral-temporal curve was generated for each polygon in order to verify the consistency of the sample.

Nine classes of land use and vegetation cover were listed for the Pampa Gaúcho biome: agricultural areas (Rice, Soybean, and Mosaic of Crops), forest, grassland, beaches and dunes, water, urban area and silviculture. The classification took into account the small differences and specific characteristics of each region, adopting a classifier trained exclusively to be used in each of them.

The DT classifier was used for the classes water, beaches and dunes, forest, silviculture and grassland. for the agricultural classes (rice, soybean and mosaic of crops), a crop mask was generated, and the DT classifier was used limited to this mask. Finally, a combination of nighttime images (DMSP-OLS) and EVI was used for the Urban Area class.

The DTs tested were constructed using the C4.5 algorithm (Quinlan, 1993) in MatLab software. The input data of the classifier were the time series itself and the land use and vegetation cover training samples, extracted from polygons selected in Landsat 8/OLI images.

The crop mask was generated using the empirical threshold method, which is recognized for its efficiency in this task (Santos et al., 2014). The threshold chosen was 0.35 
EVI (EVI threshold), obtained from visual interpretation of the difference image.

The last step corresponds to the spectral-temporal classification by DT and subsequent crossing of the classification with the flood area, generated with the HAND (height above the nearest drainage) model developed by Rennó et al. (2008), and obeying the following rule: areas classified as irrigated rice within flood areas were maintained, while areas classified as rice, but outside the flood area, were converted to the soybean class. SRTM data were processed and the HAND model was generated using the distributed hydrologic modeling system, also called TerraHidro, which is part of the TerraView platform, developed by INPE (2010). A height value of $25 \mathrm{~m}$ was adopted in the present study, as proposed by Mengue \& Fontana (2016).

The mosaic of crops class represents areas destined for agriculture, but that were not being used in the specific year (2013/2014 season). These are areas characterized by agricultural use and alternate rice and fallow with grasslands or crop rotation with rainfed cultivation. Crop masks were produced for the previous and subsequent crop years (2012/2013 and 2014/2015) and the areas of the crop masks were summed. The methodology used to generate the mosaic of crops class was the same as in the previous step for rice and soybean classes, with subsequent thresholding of the image of differences between the maximum and minimum EVI.

The urban area class was delimited using the methodology proposed by Lu et al. (2008), which is based on a combination of nighttime light images with vegetation indices. In the DMSP-OLS nighttime images used to identify the urban areas, a threshold greater than 40 was defined, which corresponds to the areas with high levels of lighting. EVI and nighttime images were reclassified to separate urban and non-urban areas in a Boolean image. The next step was to perform an overlay operation with the two Boolean images, which resulted in an image that has only nonzero values for urban areas.

To detect urban areas in the EVI images of the MODIS sensor, a threshold lower than 0.40 EVI was defined, because low EVI values represent urban areas, water bodies, bare soil etc. The EVI image date was the second half of December 2013.

The proposed methodology was validated based on two sets of information: official data from the Instituto Brasileiro de Geografia e Estatística (IBGE, 2017) and independent reference samples from the training samples directly collected in Landsat 8-OLI images. The official data of IBGE include areas cultivated with irrigated rice, soybean and silviculture area planted with forest species (eucalyptus, pine and other species) for the 106 municipalities that compose the study area, in the year 2014. The IBGE data were used only for these three classes because they are the only ones that have reference data at municipal level, applying the following statistical tests: correlation analysis (r), index of agreement (d) (Willmott et al., 1985), refined index of agreement (dr) (Willmott et al., 2012), mean error (ME) and root mean squared error (RMSE).

Finally, reference samples selected from the Landsat 8-OLI images were used for all classes of the MODIS classification.
The statistical analyses used were Kappa index (KI) and global accuracy (GA), besides the generation of confusion matrix with detailed analysis of producer's accuracy and user's accuracy per class of land use and cover.

\section{Results AND Discussion}

Figure 1 presents the map of use and vegetation cover created with MODIS images for the year 2014, evidencing that the Northern region of the study area has more intense agricultural use, especially for the Soybean class. The areas destined for the production of irrigated rice are concentrated along the main rivers and in the low areas along the Patos Lagoon. It is also possible to notice that the areas classified as grassland are distributed over the entire Pampa biome, mainly in the Western half in the surroundings of the Ibirapuitã environmental protection area. The silviculture class is concentrated mainly in Serra do Sudeste, Lower Jacuí River and Coast.

Considering the quantification of the classes in terms of area and cover percentage, the grassland class occupies the largest area, corresponding to $51.05 \%$ of the total area, while the urban area class occupies the smallest area, corresponding to $0.77 \%$ of the total area. It is important to point out that the large area destined for agricultural activities and silviculture (silviculture, rice, soybean, and mosaic of crops classes) represents $33.96 \%$ of the total area.

The global accuracy (GA) was $90.09 \%$ and the Kappa index (KI) was 0.8853 . The silviculture class presented the lowest producer's accuracy, equal to $76.24 \%$ (Table 1), while the urban area class showed the highest accuracy of 98.49\%. Studies that used similar methodology for urban area classification with MODIS images and DMSP-OLS data also have obtained positive results. Lin et al. (2014) found accuracy values higher than $75 \%$, classifying urban areas in China, with the combined use of NDVI and MODIS reflectance images and DMSP-OLS data, concluding that the result of the classification is very similar to the one with Landsat, and much better than that obtained with the MODIS product (MCD12Q1) of land cover alone. From the data presented in the confusion matrix, it was possible to observe

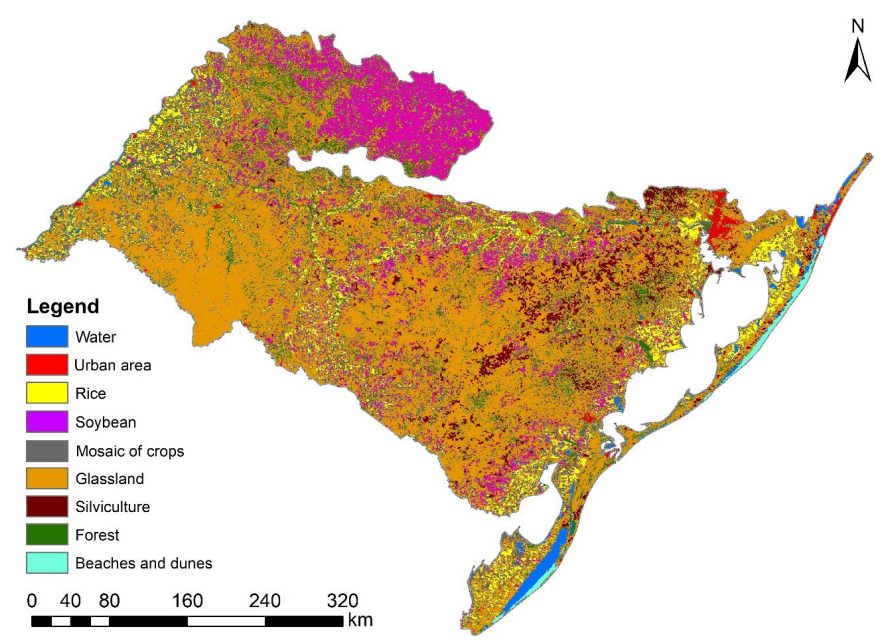

Figure 1. Land use and cover map of the Pampa biome in the year 2014, generated from MODIS sensor data 
Table 1. Confusion matrix of the map of land use and vegetation cover for the year 2014

\begin{tabular}{|c|c|c|c|c|c|c|c|c|c|c|c|}
\hline \multirow{2}{*}{$\begin{array}{c}\text { Estimated } \\
\text { class }\end{array}$} & \multicolumn{9}{|c|}{ Field class reference } & \multirow{2}{*}{ Total } & \multirow{2}{*}{$\begin{array}{c}\text { Us. Acc. } \\
(\%)\end{array}$} \\
\hline & $a$ & b & C & d & e & $f$ & g & h & $\overline{\mathbf{i}}$ & & \\
\hline A & 672 & 9 & 8 & 1 & 11 & 0 & 8 & 18 & 24 & 751 & 89.48 \\
\hline B & 0 & 1766 & 0 & 0 & 0 & 0 & 0 & 0 & 0 & 1766 & 100.00 \\
\hline C & 5 & 2 & 1297 & 1 & 37 & 1 & 12 & 0 & 4 & 1359 & 95.37 \\
\hline D & 16 & 4 & 34 & 2408 & 32 & 155 & 57 & 0 & 50 & 2756 & 87.37 \\
\hline $\mathrm{E}$ & 0 & 0 & 48 & 3 & 843 & 1 & 16 & 0 & 6 & 917 & 91.93 \\
\hline $\mathrm{F}$ & 0 & 0 & 0 & 10 & 4 & 767 & 1 & 0 & 1 & 783 & 97.96 \\
\hline G & 17 & 8 & 21 & 40 & 15 & 57 & 773 & 0 & 12 & 943 & 81.97 \\
\hline$H$ & 4 & 0 & 0 & 1 & 1 & 0 & 2 & 227 & 0 & 235 & 96.60 \\
\hline I & 26 & 4 & 129 & 32 & 76 & 25 & 25 & 0 & 1020 & 1337 & 75.17 \\
\hline Total & 740 & 1793 & 1537 & 2496 & 1019 & 1006 & 894 & 245 & 1117 & 10847 & \\
\hline Prod. Acc. (\%) & 90.81 & 98.49 & 84.38 & 96.47 & 82.73 & 76.24 & 86.47 & 92.65 & 91.32 & & \\
\hline
\end{tabular}

Prod. Acc. - Producer's accuracy; Us. Acc. - User's accurary; a - Water; b - Urban area; c - Rice; d - Grassland; e - Soybean; f - Silviculture; g - Forest; h - Beaches and dunes; i - Mosaic of crops

which classes have spectral similarities. Detailed data of the land use and vegetation cover classification evaluation are presented below.

The analysis of producer's accuracy and user's accuracy showed that the greatest spectral similarities occurred between the classes silviculture, grassland and forest. The erroneous classification, especially for the classes with vegetation cover, demonstrates the spectral and temporal similarity of the classes with vegetation cover and the difficulty to differentiate them. Hence, if only the spectral attribute was used as criteria to differentiate classes, the hit rates would be lower.

Figure 2 presents the EVI time profiles extracted from the training samples of the classes under study. For the forest class, it is possible to observe a tendency of increase in EVI during the spring and summer, which is expected once vegetation growth occurs in this period (Kuplich et al., 2013), with the increase of biomass and its specific sprouting periods, and a sharp increase in the reflectance values in the near infrared (NIR) band, causing the EVI vegetation index to increase in this period as well.

For the silviculture class, there were no differences between winter and summer, only a slight increase in EVI during the summer period, but less accentuated than that observed in forest class. It is important to emphasize that images mainly from the winter period (2013/193, 2013/209 and 2013/225) were chosen to separate the forest and silviculture classes. This period has the greatest differences of EVI between these classes, which is related to the occurrence of deciduous seasonal forest (distributed in almost all the biome, especially along the water courses) and the semideciduous seasonal forest (eastern portion of the biome, according to IBGE (2004). These classes of forests, therefore, due to their deciduous character, have as a characteristic the loss of leaves in the winter period. On the other hand, the silviculture class, for consisting mostly of plantations of the Pinus species, does not exhibit this characteristic of leaf loss, which explains the difference of EVI values in the winter period, hence constituting an important date for spectral separation and subsequent mapping.

The grassland class has the EVI temporal curve with a less accentuated difference between winter and summer periods and lower EVI values when compared to forest. The relatively small variation of the temporal curve of grassland class throughout the winter and summer period, according to Boldrini (2009), is associated with the highest availability of energy (radiation and air temperature) in the summer, as well as the growth of C3 species in autumn and winter, and C4 in summer along the natural pastures of the Pampa biome. The spectral-temporal curve of the grassland class is similar to those found in the studies of Jacóbsen et al. (2004), Wagner et al. (2013) and Scottá \& Fonseca (2015). The images of the summer period were used to spectrally separate the grassland

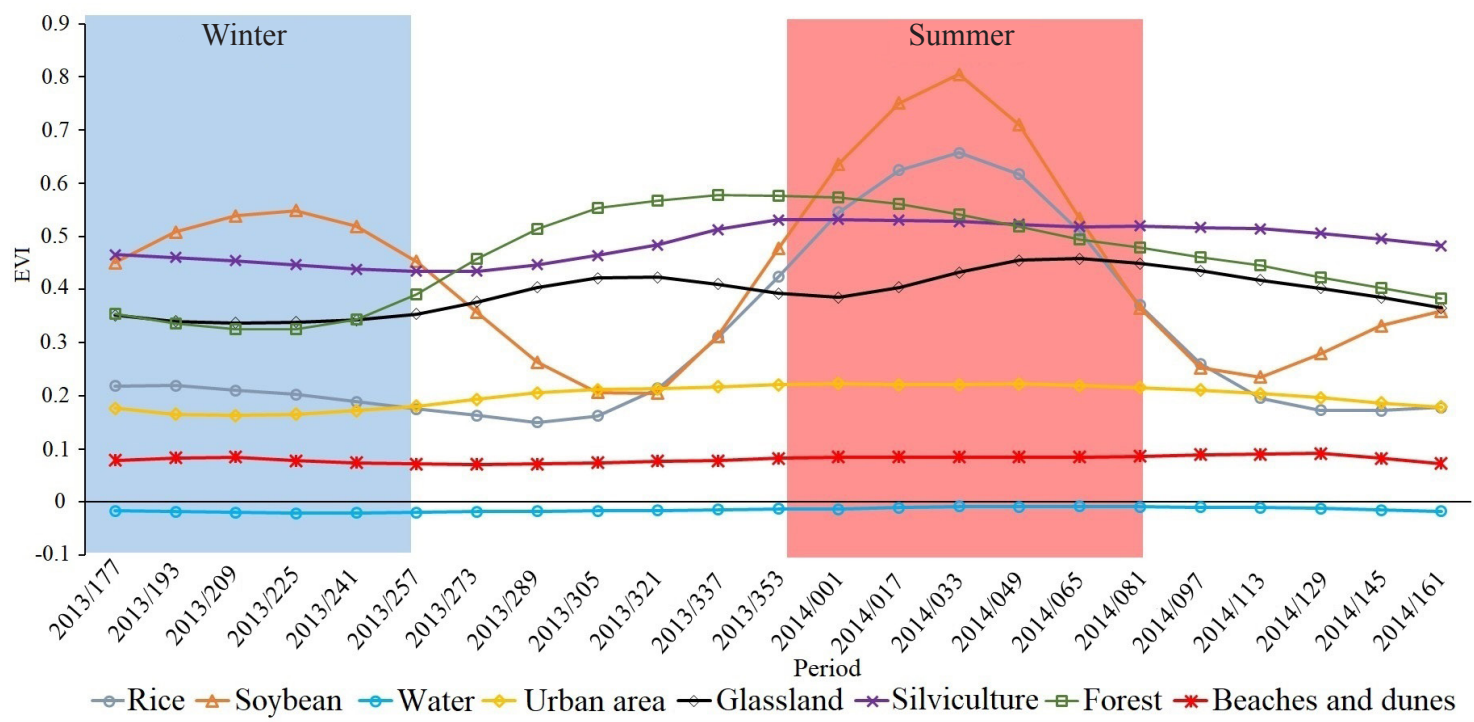

Figure 2. MODIS- EVI time profiles for the classes of land use and vegetation cover of the year 2014 
class from the classes silviculture and forest, since this period (especially on the dates of acquisition of the images 2013/353, 2014/001 and 2014/017) has the largest differences in EVI.

The urban area class had the best results of the producer's accuracy, with $98.49 \%$ of hit. The combination of nighttime images (DMSP-OLS) with the image of EVI $<0.40$ was able to eliminate the chance of erroneously classifying those classes with spectral similarity, such as the classes Water and Beaches and Dunes.

The classification errors observed for the classes Silviculture and Grassland may be related to the shape and spatial organization of silviculture areas, mainly in those located in Serra do Sudeste, close to the municipalities of Bagé, Encruzilhada do Sul and Piratini, where the frequency of this class is very high. The shape and distribution between grassland or low vegetation areas can be one of the indicators of spectral similarity between classes.

The classes of agricultural use, such as rice and soybean, showed producer's accuracy of 84.38 and $82.73 \%$, respectively. The greatest spectral similarities were between the classes mosaic of crops, soybean and rice. It was found that the generation of the crop mask and its use in the classification process was a fundamental step for correctly separating annual crops from the other classes.

The elaboration of maximum and minimum EVI images during the summer period and subsequent generation of the difference image was also able to correctly select the areas where there is variation of EVI, which is characteristic of summer annual crops. Several studies have confirmed that this methodology for identifying crop masks, which uses the temporal attribute in sequentially arranged MODIS series, has a high potential for hits (Johann et al., 2012; Victoria et al., 2012; Mengue \& Fontana, 2015).

Figure 3 presents the decision tree (DT) for the classes rice and soybean, applied in the area selected by the crop mask, defined by the thresholding of the image of maximum and minimum EVI. Three important periods were selected. The root of the tree (upper part) selects an image that represents the period preceding the beginning of the cycle (2013/225) in August, indicating that the data recorded in this period are determinant for the separation between the two crops. The preparation of the land for rice cultivation requires greater systematization of the area due to the use of flood irrigation. This prevents cultivation in the winter period, leading to low and stable EVI values in the period, typical of bare soil.

The second period that the algorithm refers to the month of February (2014/033), a period in which soybean and rice have a large accumulation of biomass, but with higher values associated with soybean. This is typical of leguminous species, but also results from the influence of irrigation water on rice,

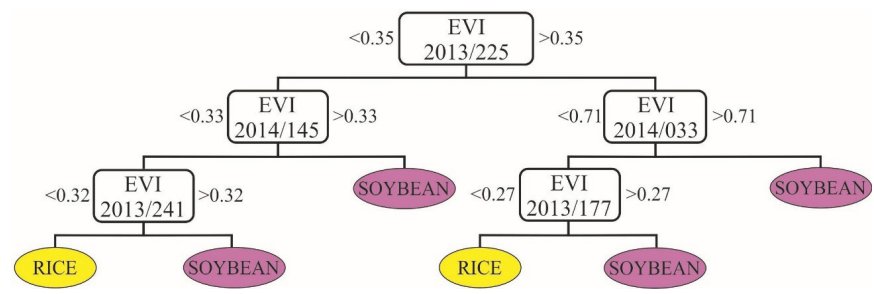

Figure 3. Decision tree (DT) defined by the C4.5 algorithm for the rice and soybean classes which contributes to the decrease of the index. The third period selected was in May (2014/145), after the harvest of both crops, and when soybean areas have higher EVI values when compared to rice areas.

The EVI values used for the spectral separation criterion were between 0.32 and 0.35 , both in the period preceding the beginning and at the end of the crop cycle. In the areas destined for soybean cultivation, especially in the Northern portion of the Pampa biome, the temporal curve of EVI for the soybean crop has two peaks per year: in summer, associated with soybean cultivation, and in the winter period, associated with the cultivation of cereals. In rice areas, there is no second cycle in the winter period.

It is important to point out that the flood area generated with the HAND model was an important criterion to separate low areas (floodplains) from higher areas. The floodplain area $(<25 \mathrm{~m})$ mapped with the HAND model occupies $9,834,202.52$ ha, representing $59.62 \%$ of the total area of the Pampa biome. Therefore, in a large part of the Pampa biome, where the relief is gently undulating and where it is viable to obtain water for irrigation, the conditions are appropriate for the cultivation of irrigated rice.

It is also worth pointing out that only part of the floodplain area mapped with the HAND model is effectively used for cultivation with irrigated rice. Klering et al.(2013), using a series of 10 crop years, identified with MODIS images a potential area for use with irrigated rice of 3,322,037 ha.

The crossing of flood areas (HAND) with Rice class generated a total cultivated area of 1,134,972 ha for the 2014 crop (Table 2). Although the result overestimated by $12.83 \%$ the IBGE's official value of $1,005.915$ ha, it came closer than the initial value without the crossing with the HAND model, which was $1,260,271$ ha. The same occurred with the soybean class, which, after crossing with the flood area, generated an area of $1,601,685$ ha, underestimating by $11.37 \%$ the official value of IBGE, equivalent to $1,807.109$ ha (Table 2), and being closer to the initial value without the crossing with the HAND model, which was $1,477,139$ ha. Therefore, if the official estimates are considered as a reference, the overestimation for the rice class and the underestimation for the soybean class can be seen as an indicator that the soybean cover areas in the Pampa biome are over floodplain areas (mapped with the HAND model).

Table 2. Official cover area (IBGE, 2017) and cover area values obtained with the MODIS-EVI classification for the classes soybean, irrigated rice, and silviculture

\begin{tabular}{lccc}
\hline \multicolumn{1}{c}{ Variables } & Soybean & $\begin{array}{c}\text { Irrigated } \\
\text { rice }\end{array}$ & Silviculture \\
\hline IBGE official area (ha) & $1,807,109$ & $1,005,915$ & 491,707 \\
MODIS area (ha) & $1,601,685$ & $1,134,972$ & 561,835 \\
Difference (MODIS-IBGE) (ha) & $-205,424$ & 129,057 & 70,128 \\
Difference (\%) & -11.37 & 12.83 & 14.26 \\
Mean error - ME (ha) & $-1,937.97$ & $1,217.52$ & 661.58 \\
RMSE (ha) & $8,821.3$ & $3,935.9$ & $4,098.1$ \\
Willmott' index of agreement (d) & 0.9783 & 0.9893 & 0.9293 \\
Willmott's refined index & 0.8704 & 0.8822 & 0.7406 \\
of agreement (dr) & 0.9452 & 0.9766 & 0.7870 \\
\hline Correlation coefficient (r) & & & \\
\hline
\end{tabular}

RMSE - Root mean square error 
Therefore, from the methodological point of view, it is important to emphasize that the criterion of EVI variability along the cycle should not be used alone for separation between rice and soybean in the region. The context of the cultivation, introduced in this work by the location of the areas relative to the nearest drainage (HAND), was fundamental for obtaining better results.

The rice class showed a correlation coefficient $(r)$ of 0.9766 , higher than that for the silviculture class, with $r=0.7870$. The mean error (ME) at municipal level obtained an overestimation for the rice and silviculture classes, with 1,217.52 and 661.58 ha respectively, and an underestimation for the Soybean class of 1,937.97 ha. It is important to point out that, in the silviculture class, the classification data are inadequate for small plots. This is consistent with the previously presented aspect related to the occupation form of the territory, and the probable inadequacy of the MODIS images in the areas of the forest parks.

The RMSE, more sensitive to major errors, for raising the individual differences to the second power and presenting error values in the same dimensions as that of the analyzed variable, was the lowest for the rice class, 3,935.9 ha, and the highest for the soybean class, 8,821.3 ha.

Finally, it is important to remember that the official data of IBGE are estimates that carry a certain degree of uncertainty, characteristic of this type of survey. It is also important to remember that, when there are differences between data obtained by the proposed methodology and the official data, it is difficult to conclude which methodology is closer to reality.

\section{Conclusions}

1. The land use and vegetation cover map for the Pampa biome produced for the year 2014 showed quantitative results in terms of area compatible with the data recorded by IBGE.

2. The methodology for estimating the flood area through the HAND model proved to be efficient in separating floodplain areas, increasing the accuracy of the classification by decision tree (DT) between the rice class and other classes with coincident cycles, such as the soybean class.

3. Despite the limitation of DMSP-OLS data, due to the spatial resolution of $550 \mathrm{~m}$, its use combined with the EVI images of the MODIS sensor with $250 \mathrm{~m}$ resolution, generating results with a considerable high mapping quality, mainly in larger and more densely occupied urban areas, where there is greater nighttime lighting levels.

4. The decision tree (DT) classifier was important as an indicator of the best periods to separate classes and to better understand the temporal dynamics and what are the periods with the best spectral separability.

\section{Literature Cited}

Boldrini, I. I. A flora dos campos do Rio Grande do Sul. In: Pillar, V. de P.; Müller, S. C.; Castilhos, Z. M. S.; Jacques, A. V. A. (eds.). Campos Sulinos: Conservação e uso sustentável da biodiversidade. Brasília: MMA, 2009. 403p.
Brown, J. C.; Kastens, J. H.; Coutinho, A. C.; Victoria, D. C.; Bishop, C. R. Classifying multiyear agricultural land use data from Mato Grosso using time-series MODIS vegetation index data. Remote Sensing of Environment, v.130, p.39-50, 2013. https:// doi.org/10.1016/j.rse.2012.11.009

Cao, X.; Chen, J.; Imura, H.; Higashi, O. A SVM-based method to extract urban areas from DMSP-OLS and SPOT VGT data. Remote Sensing of Environment. v.113, p.2205-2209, 2009. https://doi.org/10.1016/j.rse.2009.06.001

Epiphanio, R. D. V.; Formaggio, A. R.; Rudorff, B. F. T.; Maeda, E. E.; Luiz, J. B. Estimating soybean crop areas using spectraltemporal surfaces derived from MODIS images in Mato Grosso, Brazil. Pesquisa Agropecuária Brasileira, v.45, p.72-80, 2010. https://doi.org/10.1590/S0100-204X2010000100010

IBGE - Instituto Brasileiro de Geografia e Estatística. Mapa da vegetação do Brasil. Rio de Janeiro: Ministério do Planejamento, Orçamento e Gestão, 2004. Available on: <https://ww2.ibge.gov. br/home/presidencia/noticias/21052004biomas.shtm $>$. Access on: Feb. 2016.

IBGE - Instituto Brasileiro de Geografia e Estatística. Banco de Dados Agregados: Sistema IBGE de Recuperação Automática - SIDRA. 2017. Available on: <http://www.sidra. ibge.gov.br>. Access on: Jan. 2017.

INPE - Instituto Nacional de Pesquisas Espaciais. TerraView 4.5.0. São José dos Campos: INPE. 2010. Available on: <http://www. dpi.inpe.br/terraview>.Access on: Nov.2016.

Jacóbsen, L. O.; Fontana, D. C.; Shimabukuro, Y. E. Efeitos associados a El Niño e La Niña na vegetação do Estado do Rio Grande do Sul, observados através do NDVI/NOAA. Revista Brasileira de Meteorologia, v.19, p.129-140, 2004.

Johann, J. A.; Rocha, J. V.; Duft, D. G.; Lamparelli, R. A. C. Estimativa de áreas com culturas de verão no Paraná, por meio de imagens multitemporais EVI/Modis. Pesquisa Agropecuária Brasileira, v.47, p.1295-1306, 2012. https://doi.org/10.1590/ S0100-204X2012000900015

Jönsson, P.; Eklundh, L. TIMESAT: A program for analyzing timeseries of satellite sensor data. Computers \& Geosciences, v.30, p.833-845, 2004. https://doi.org/10.1016/j.cageo.2004.05.006

Klering, E. V.; Fontana, D. C.; Alves, R.; Rocha, J.; Berlato, M. A. Estimativa de área cultivada com arroz irrigado para o estado do Rio Grande do Sul a partir de imagens Modis. Ciência e Natura, v.35, p.126-135, 2013. https://doi.org/10.5902/2179460X12567

Köppen, W. Climatología: Con un estudio de los climas de la tierra. México, DF: Fondo de Cultura Económica, 1948. 71p.

Kuplich, T. M.; Moreira, A.; Fontana, D. C. Série temporal de índice de vegetação sobre diferentes tipologias vegetais no Rio Grande do Sul. Revista Brasileira de Engenharia Agrícola e Ambiental, v.10, p.11161123, 2013. https://doi.org/10.1590/S1415-43662013001000014

Lin, J.; Liu, X.; Li, K.; Li, X. A maximum entropy method to extract urban land by combining MODIS reflectance, MODIS NDVI, and DMSP-OLS data. International Journal of Remote Sensing, v.35, p.6708-6727, 2014. https://doi.org/10.1080/01431161.2014 .960623

Liu, Y.; Wang, X.; Guo, M.; Tani, H.; Matsuoka, N.; Matsumura, S. Spatial and temporal relationships among NDVI, climate factors, and land cover changes in Northeast Asia from 1982 to 2009. GIScience and Remote Sensing, v.48, p.371- 393, 2011. https://doi.org/10.2747/1548-1603.48.3.371 
Lu, D.; Tian, H.; Zhou, G.; Ge, H. Regional mapping of human settlements in Southeastern China with multisensor remotely sensed data. Remote Sensing of Environment, v.112, p.36683679, 2008. https://doi.org/10.1016/j.rse.2008.05.009

Maraschin, G. E. Manejo do campo nativo, produtividade animal, dinâmica da vegetação e adubação de pastagens nativas do sul do Brasil. In: Pillar, V. P.; Müller, S. C.; Castilhos, Z. M. S.; Jacques, A. V. A. (eds.). Campos Sulinos: Conservação e uso sustentável da biodiversidade. Brasília: MMA, 2009. p.248-259.

Mengue, V. P.; Fontana, D. C. Avaliação da dinâmica espectrotemporal visando o mapeamento dos principais cultivos de verão no Rio Grande do Sul. Bragantia, v.74, p.331-340, 2015. https://doi.org/10.1590/1678-4499.0452

Mengue, V. P.; Fontana, D. C. Identification of suitable areas for irrigated rice cropping using MODIS images and HAND model. Engenharia Agrícola, v.36, p.329-341, 2016. https://doi. org/10.1590/1809-4430-Eng.Agric.v36n2p329-341/2016

NASA - National Aeronautics and Space Administration. Jet Propulsion Laboratory. California Institute of Technology. The Shuttle Radar Topography Mission collected topographic data over nearly 80 percent of Earth's land surfaces, creating the firstever near-global data set of land elevations. NASA. Available at: http://www2.jpl.nasa.gov/srtm/mission.htm. 2000.

Nobre, A. D.; Cuartas, L. A.; Hodnett, M.; REnnó, C. D.; Rodrigues, G.; Silveira, A.; Waterloo, M.; Saleska, S. Height above the Nearest Drainage, a hydrologically relevant new terrain model. Journal Hydrology. v.404, p.13-29, 2011. https://doi.org/10.1016/j. jhydrol.2011.03.051

Quinlan, J. R. C4.5: Programs for machine learning. San Francisco: Morgan Kaufmann, 1993. 302p.

Rennó, C. D.; Nobre, A. D.; Cuartas, L. A.; Soares, J. V.; Hodnett, M. G.; Tomasella, J., Waterloo. M HAND, a new terrain descriptor using SRTM-DEM: Mapping terra-firme rainforest environments in Amazonia. Remote Sensing of Environment, v.112, p.34693481, 2008. https://doi.org/10.1016/j.rse.2008.03.018
Santos, J. dos S.; Fontana, D. C.; Silva, T. S. F.; Rudorff, F. T. Identificação da dinâmica espaço-temporal para estimar área cultivada de soja a partir de imagens MODIS no Rio Grande do Sul. Revista Brasileira de Engenharia Agrícola e Ambiental, v.18 p.54-63, 2014. https://doi.org/10.1590/S1415-43662014000100008

Scottá, F. C.; Fonseca, E. L. da. Multiscale trend analysis for pampa grasslands using ground data and vegetation sensor imagery. Sensors, v.15, p.17666-17692, 2015. https://doi.org/10.3390/ s150717666

SATVEG - Sistema de Análise Temporal da Vegetação. Available on: <https://www.satveg.cnptia.embrapa.br/satveg/login.html>. Access on: Sep. 2016.

Victoria, D. de C.; Paz, A. R. da; Coutinho, A. C.; Kastens, J.; Brown, J. C. Cropland area estimates using Modis NDVI time series in the state of Mato Grosso, Brazil. Pesquisa Agropecuária Brasileira, v.47, p.1270-1278, 2012. https://doi.org/10.1590/ S0100-204X2012000900012

Wagner, A. P. L.; Fontana, D. F.; Fraisse, C.; Weber, E. J.; Hasenack, H. Tendências temporais de índices de vegetação nos campos do Pampa do Brasil e do Uruguai. Pesquisa Agropecuária Brasileira, v.48, p.1192-1200, 2013. https://doi.org/10.1590/S0100204X2013000900002

Willmott, C. J.; Ackleson, S. G.; Davis, R. E.; Feddema, J. J.; Klink, K. M.; Legates, D. R.; O'Donnell, J.; Rowe, C. M. Statistics for the evaluation and comparison of models. Journal of Geophysical Research, v.90, p.8995-9005, 1985. https://doi.org/10.1029/ JC090iC05p08995

Willmott, C. J.; Robeson, S. M.; Matsuura, K. A refined index of model performance. International Journal of Climatology, v.32, p.2088-2094, 2012. https://doi.org/10.1002/joc.2419

Zhou, F.; Zhang, A.; Townley-Smith, L. A data mining approach for evaluation of optimal time-series of MODIS data for land cover mapping at a regional level. Journal of Photogrammetry and Remote Sensing, v.84, p.114129, 2013. https://doi.org/10.1016/j. isprsjprs.2013.07.008 